\title{
Demolition as a Territorial Reform Project
}

\author{
Chiara Merlini
}

\begin{abstract}
The widespread conditions of obsolescence and risk emerging in many parts of our country pose new questions to the territorial project and entail a review of its operational tools. In this sense, even demolition can acquire a new meaning, soliciting a technical and cultural reflection that has repercussions on future of the contemporary territory.
\end{abstract}

Keywords Decline $\cdot$ Demolition $\cdot$ Urban planning $\cdot$ Volumetric transfer $\cdot$ Urbanity

\section{Introduction: Decline and Risk}

The following notes will argue that the territorial project can usefully reconsider demolition as its operational tool and that, more generally, the notion itself of demolition must be reconceptualised. The assumption is that the current conditions of our country push us to consider in new ways potential removal actions of built heritage, giving them a broad spectrum of meanings and recovering the complexity of a term too often used in reductive ways (Terranova 1997; Criconia 1998; Nigrelli 2005; Merlini 2008, 2019).

Two main aspects can be called upon as a reference background, in relation also to a substantial convergence of representations provided by the latest urban and territorial studies (Calafati 2014; Munarin and Velo 2016; Fabian and Munarin 2017; De Rossi 2018).

First of all, the issue of decline, which is today, linked in a new way to surplus built space. In some parts of the country, housing stock is in excess compared to the people's request, with the resultant occurrence of underutilization and abandonment phenomena. In particular, a new phenomenology arises in which the peculiar entanglement between economic crisis and demographic contraction broadens the

\section{Merlini (殴}

Architecture, Built Environment and Construction Engineering-ABC Department, Politecnico di Milano, Milan, Italy

e-mail: chiara.merlini@polimi.it 
set of impoverishing objects. To the traditional emptying of large urban 47 equipment and to the 20th-century production dismantling, territorial situations are added characterized by the obsolescence of smaller and dispersed buildings (Lanzani 2015).

What we are thus called upon to face is therefore not only a quantitatively significant phenomenon, linked to the growing disproportion between the space availability and concretely actionable demand, which is of course connected to the drastic reduction in public and private resources. It is precisely the specific nature of the artefacts affected by underutilisation and/or abandonment that must be highlighted. More and more we are dealing with ordinary and anonymous buildings, essentially devoid both of value, and of those elements of suggestion that had sometimes the big factories protagonists of the first phases of urban dismantling.

There are several examples: the condominium incorporated in many urban centres after World War II; the prefabricated industrial building on the edge of production areas or along roads that no longer ensure adequate levels of services and appropriate accessibility; the family home in città diffusa settlement in which the system of expectations and preferences has drastically changed with the generational change; the second home in tourist areas made less attractive by climate change or by congestion; the shopping centre along market streets that are no longer sufficiently dynamic, and so on. Buildings that in the phase of the country's intense growth that is now behind us have incorporated significant economic and symbolic investments and now suffering from the crisis. These are artefacts that are poor in terms of architectural and construction quality, poorly placed on the territory, without recognizable surroundings or a proximity space; in effect the result of urban policies that is not very context-conscious and of construction processes often conducted in economics. Aged prematurely, they often witness a drastic reduction in the property value, that makes their fate very uncertain.

Secondly, it is now evident that large portions of our country disclose increasingly dramatic risk conditions (Fabian and Munarin 2017). It is a territorial fragility expressed in a variety of ways: hydrogeological instability, deficient maintenance and static uncertainty of buildings and infrastructures, seismic risk, construction sites never completed, and air and soil pollution. Recent reports on the state of the territory measure some of the effects of the long cycle of urbanisation, investigating the relationships with the broader dynamics of climate and demographic change. What emerges, beyond the obvious territorial differences, is an increasingly more fragile country where the very elements that over the long-term have built it main structure, such as hydrographical and infrastructural networks, fall into a crisis.

Faced with these issues-abandoned building stock and risk-the question is whether generalized actions of securing the country and urban regeneration are really viable, or whether there we should not rather consider that this may not always be possible. There are plentiful reasons: the growing uncertainty of real estate transactions based on replacement building, the difficult management of reuse and recycling processes, often unsustainable in terms of economic investments, seemingly shape up a rather uncertain situation (Micelli 2014).

The complexity of the current conditions pushes us, in other words, to advance different working hypotheses, which consciously take note of territorial situations 
that are not always recoverable, which must therefore eventually be removed or accompanied in a process of decline. Not everything can be saved, reused, enhanced from a recycling perspective (Corbellini and Marini 2016). And this of course raises considerable problems in a cultural context marked by the centrality of memory and by the symmetrical distrust about future (Andriani 2010; Bauman 2017). There is an entire research field that should probably be reformulated, and in which, even demolition can regain an important planning role. And this of course involves technical questions as questions pertaining to the value assigned to the inherited assets and to the possible redefinition of contemporary settlements.

\section{Demolition, Between Failure and Promise}

A demolition is a violent act: destruction is its constitutive and unavoidable part, and so its ambition to be a conclusive action. But it is also an act of repair, a kind of compensation and/or promise. In the recent history of urban transformation, at least in our country, demolition has acquired, somewhat simplistically, a dual meaning. On the one hand, it was considered an event, an anomaly reserved for a few exceptional cases loaded with symbolic meaning; on the other, it was the slightly hidden face of a more ordinary transformation process that has perhaps overestimated the qualitative effects of building replacement interventions.

The first case includes those demolitions that take up a compensatory value, either because they have the effect of correcting for the violation of a rule and damage suffered, as occurs with the removal of illegal buildings in a valuable landscape (Curci et al. 2017), or because they put an end to a recognized failure, as in the case of some buildings that represent the problematic legacy of modernity. In the second case, there are the demolitions describable as a precondition of a real estate development process. The tabula rasa is considered here an opportunity, as can be read in the debate on industrial dismantling (Russo 1998; Dansero et al. 2001), but also in ordinary demolition action often guided by an economistic logic or from the safeguarding constraints. To make a tabula rasa to rebuild was, in other words, a non-problematized process, both in relation to what was removed, and in relation to the new building production, often architecturally modest, not very ecologically virtuous and incapable of defining articulated and complex urban relationships.

Two ways of considering demolition often made even more ambiguous by a further simplification, which reduced the urban quality to the removal of the "ugly" with the conviction that it was a necessary step in a process of modernization. Deviation from the norm, removal of an aesthetic damage, recovery of a public asset, promise of an urban development responding to new housing needs and capable of supporting the construction industry: these were the main terms of a discourse on demolition that oscillated between overexposure and indifference. Hence, the need for conceptual and operational repositioning (Merlini 2019). 


\section{Reorganization. Remove on One Side, Remit It on the Other}

Facing a demolition's representation of this kind, the current territorial conditions introduce inevitable elements of complexity and force us to reformulate the terms. For the urban project, two perspectives emerge in particular.

On the one side, a partial and selective demolition, like what has been done in recent public housing redevelopment projects, in which the residual value assigned to the building and the recycling of the materials removed is accompanied by the redefinition of urban relations (Infussi and Orsenigo 2008; Laboratorio città pubblica 2009; Di Palma 2011; Lepratto 2017). On the other side, an idea of demolition where the building's value is dematerialised and transferred elsewhere, becoming the tool for a broader territorial reorganisation design.

This second aspect deserves to be more investigated by referring, for example, to the role that demolition could play in the redevelopment of those parts of the città diffusa that are facing a greater crisis today. The generally modest quality of these territories, the loss of attractiveness, the social composition with increasing amounts of elderly population, the high levels of pollution, and soil waterproofing, poses new challenges to urban planning.

In particular, underutilisation phenomena emerge, often linked to a general redefinition of relations between living spaces and workplaces. This is attested, for example, by the changing of the family house, which has had a big impact on the urbanisation processes between the 1960s and 1990s, both in the single-house format and in hybridisations with working spaces. A space that is no longer able to intercept the preferences and investments of the new generations, who sometimes see that inheritance more as a burden than as an advantage (Merlini and Zanfi 2014). Or it is attested - to give another example — by the production building in which add up the obsolescence, the inefficient accessibility, the dearth of support services for the company, the criticality of a landscape impact.

These buildings do not always show advanced degradation conditions, but nevertheless it is difficult to imagine them in a redevelopment perspective what restores them to a new life cycle (Zanfi and Curci 2018). In such situations, a responsible judgment is forced to be selective and also consider the possibility of demolition, because of a number of factors that consider the scarcity of available economic resources, while also promoting a territorial vision aimed at restoring security and urbanity conditions. For the urban design, a reflection therefore opens up that primarily seeks to recognize those situations in which it is possible to recover and transfer value, through mechanisms of subtraction and addition of volumes. It is essentially a case of promoting a reorganisation process based on identifying source areas and areas of fall in volumes, made operational through volumetric transfer mechanisms, while also evaluating the factors that ensure economic feasibility (Lanzani et al. 2014).

Demolition is in this case the tool of a territorial reorganisation that recognizes a divergence of values. On the one hand, buildings that decline and that might have a future only through the value generated by their volumetric rights; on the other, 
more dynamic situations where new volumes could be an opportunity for urban consolidation. The task of urban planning would naturally be to identify and adjust areas of departure and relapse of the volumes, responding not only to the need to restrict the soil consumption bat, more generally, to issues relating to safety and urbanity of settlements.

This territorial reorganization should have a dual requirement. First, it is a matter of removing buildings that are in decline, abandoned or located in improper places, which cause problems of insecurity, or involving unsustainable maintenance and management costs. Demolition would be based on a very relevant technical topicwhat produces risk must be demolished-which reconfigures its terms. At the same time, it would generate volumes to consolidate parts of the existing city, especially where the settlements are less defined and where they could benefit from the introduction of new volumes. In essence, a demolition and a densification that, through specific intervention rules, can contribute to the necessary reflection on the urbanity forms of contemporary territories.

But it's not just about this. A further element emerges in this territorial reorganization project. When a building in decline or an impermeable soil is removed, a naturalization and remediation action (granted in fact by the presence, elsewhere, of an improvement) should be combined (Girot 2005). The terms of the problem are: more security, more urbanity, but also more nature.

The development of a procedural mechanism allowing volumetric transfers should, in this sense, be part of a wider territorial vision, which could partially redefine our very idea of nature. Some partial demolition could in fact collaborate in defining a new landscape in the città diffusa contexts. A re-naturalization that takes its distances from a restoration idea (unthinkable in a landscape that has drastically changed the original agricultural use and hybridized its expressive codes), and can also be activated through actions that, like the demolitions might be partial.

The removal of the most critical elements from an environmental viewpoint, accompanied by low-cost interventions (for example, simple carry-over of land and sowing), could trigger a reconfiguration process with significant landscape effects and, at the same time, might change our imaginary. Partial removals, even small and episodic, could give shape to parts of non-domesticated nature, offered to visual perception but subtracted from use (Clément 2005).

\section{Conclusions}

What is synthetically exposed is a change of perspective that has unavoidable technical and cultural complexities opening up reflections in multiple directions. For example, it becomes necessary to review the regulatory framework traceable to the waste cycle (Rigamonti 1996), redefine the organization of the dismantling and demolition sites that could be temporarily shape up as storage depots, and more generally rethink the concept of risk. 
This takes us back to a more general theme, which cannot of course be developed here. The phenomena mentioned at the beginning urge a reflection on the possible presence, in next future, of buildings destined to decline because no transformation will be activated on them, and no economic resources will be available, not even for their demolition. For them, perhaps only a scenario of permanent abandonment opens up. This will have to be managed knowing that the possibility that they can turn into ruin with a certain symbolic and testimonial value is limited, and that, more likely, we will be forced to coexist with waste and rubble (Augé 2004; Broggini 2009; Lanzani and Curci 2018).

\section{References}

Andriani, C. (Ed.). (2010). Il patrimonio e l'abitare. Roma: Donzelli.

Augé, M. (2004). Rovine e macerie. Il senso del tempo, (2003). Torino: Bollati Boringhieri.

Bauman, Z. (2017). Retrotopia. Roma-Bari: Laterza.

Broggini, O. (2009). Le rovine del Novecento. Rifiuti, rottami, ruderi e altre eredità. Reggio Emilia: Diabasis.

Calafati, A. (Ed. 2014), Città tra sviluppo e declino: un'agenda urbana per l'Italia. Roma: Donzelli. Clément, G. (2005). Manifesto del terzo paesaggio, (2004). Macerata: Quodlibet.

Corbellini, G., \& Marini, S. (Eds.). (2016). Recycled theory. Quodlibet, Macerata: Dizionario illustrato.

Criconia, A. (Ed.). (1998). Figure della demolizione. Il carattere instabile della città contemporanea. Genova Milano: Costa \& Nolan.

Curci, F., Formato, E., \& Zanfi, F. (Eds.). (2017). Territori dell'abusivismo. Un progetto per uscire dall'Italia dei condoni. Roma: Donzelli.

Curci, F., Zanfi, F. (2018). "Il costruito, tra abbandoni e riusi". In A. De Rossi (Ed.), Riabitare l'Italia. Le aree interne tra abbandoni e riconquiste (pp. 207-231). Roma: Donzelli.

Dansero, E., Giaimo, C., Spaziante, A. (Eds.). (2001). Se i vuoti si riempiono. Aree industriali dismesse: temi e ricerche. Firenze: Alinea.

De Rossi, A. (Ed.). (2018). Riabitare l'Italia. Donzelli, Roma: Le aree interne tra abbandoni e riconquiste.

Di Palma, V. (2011). Demolizione e ricostruzione nei programmi di riqualificazione urbana. Roma: Aracne.

Fabian, L., \& Munarin, S. (Eds.). (2017). Re-Cycle Italy. Lettera Ventidue, Siracusa: Atlante.

Girot, C. (2005). "Vers une nouvelle nature". In Aa. Vv, Landscape Architecture in Mutation. Essay on Urban Landscape (pp. 19-33). Zurich: Eth.

Infussi, F. \& Orsenigo, G. (Eds.). (2008). "Progetto di demolizione. Viaggio ai confini del moderno". In Territorio, n. 45, pp. 9-62.

Laboratorio Città Pubblica (2009). Città pubbliche. Linee guida per la riqualificazione urbana, Bruno Mondadori, Milano.

Lanzani, A. (2015). Città territorio urbanistica tra crisi e contrazione. Milano: Angeli.

Lanzani, A., Merlini, C. \& Zanfi, F. (2014). "Quando 'un nuovo ciclo di vita' non si dà. Fenomenologia dello spazio abbandonato e prospettive per il progetto urbanistico oltre il paradigma del riuso". In Archivio di Studi Urbani e Regionali, n. 109, 28-47.

Lanzani, A., Curci, F. (2018). "Le Italie in contrazione, tra crisi e opportunità". In A. De Rossi (Eds.), Riabitare l'Italia. Le aree interne tra abbandoni e riconquiste (pp. 79-107). Roma: Donzelli.

Lepratto, F. (2017). Bricolage urbano. Il progetto contemporaneo per trasformare la residenza collettiva del secondo dopoguerra: obiettivi, metodi, strumenti. Dottorato di ricerca in Architettura, Urbanistica e Conservazione dei luoghi dell'abitare e del paesaggio, Politecnico di Milano. 
Merlini, C. (2008). "La demolizione tra retoriche e tecniche del progetto urbano", in Territorio, n. 45 , pp. 49-55.

Merlini, C. (2019). "L'eventualità della demolizione. Forme, situazioni e linguaggi". Archivio di Studi Urbani e Regionali, n. 124, pp. 26-48.

Merlini, C., \& Zanfi F. (2014). "The family houses and its territories in contemporary Italy: present conditions and future perspectives". In Journal of Urbanism, 9, pp. 221-244.

Micelli, E. (2014). "L'eccezione e la regola. Le forme della riqualificazione della città esistente tra demolizione e ricostruzione e interventi di riuso". In Valori e Valutazioni, n. 12, pp. 11-20.

Munarin, S., \& Velo, L. (Eds.). (2016). Italia 1945-2045. Urbanistica prima e dopo. Radici, condizioni, prospettive. Roma: Donzelli.

Nigrelli, F. C. (Ed.). (2005). Il senso del vuoto. Manifestolibri, Roma: Demolizioni nella città contemporanea.

Rigamonti, E. (1996). Il riciclo dei materiali in edilizia. Sant'Arcangelo di RomagnaL: Maggioli. Russo, M. (1998). Aree dismesse. Forma e risorsa della "città esistente". Napoli: Edizioni Scientifiche Italiane.

Terranova, A. (Ed.). (1997). Il progetto della sottrazione. Roma: Croma Quaderni n. 3.

Open Access This chapter is licensed under the terms of the Creative Commons Attribution 4.0 International License (http://creativecommons.org/licenses/by/4.0/), which permits use, sharing, adaptation, distribution and reproduction in any medium or format, as long as you give appropriate credit to the original author(s) and the source, provide a link to the Creative Commons license and indicate if changes were made.

The images or other third party material in this chapter are included in the chapter's Creative Commons license, unless indicated otherwise in a credit line to the material. If material is not included in the chapter's Creative Commons license and your intended use is not permitted by statutory regulation or exceeds the permitted use, you will need to obtain permission directly from the copyright holder. 